\title{
The metastasis-inducing protein AGR2 is $O$-glycosylated upon secretion from mammary epithelial cells
}

\author{
Christopher Clarke $^{1} \cdot$ Philip Rudland $^{1} \cdot$ Roger Barraclough ${ }^{1}$
}

Received: 24 April 2015/Accepted: 4 July 2015/Published online: 14 July 2015

(C) The Author(s) 2015. This article is published with open access at Springerlink.com

\begin{abstract}
AGR2 is overexpressed in multiple cancers, particularly those arising from breast and prostate tissues, and higher levels of AGR2 are associated with earlier patient death. Although AGR2 is normally resident within the endoplasmic reticulum, the protein has been found in the extracellular space in several model systems. However, it has never been expressly demonstrated that this extracellular form of the protein is secreted and does not just accumulate in the extracellular space as a result of cell lysis. We show in this paper that AGR2 protein is secreted by both human and rat mammary epithelial cells in culture. Furthermore, this secreted form of AGR2 becomes $O$ glycosylated, with no detectable presence of $N$-glycosylation. Importantly, this post-translationally modified AGR2 is only detected in the conditioned medium from non-leaky cells, suggesting that membrane integrity must be maintained to allow AGR2 glycosylation. The results suggest a possible role for $O$-glycosylation in modulating the extracellular functions of AGR2.
\end{abstract}

Keywords AGR2 - Glycosylation · Secretion · Adhesion

\section{Introduction}

Anterior gradient protein 2 (AGR2) is a member of the protein disulphide isomerase family of endoplasmic reticulum (ER) chaperones [1], and its major role to date appears to be in promoting the secretion of several mucin

Roger Barraclough

brb@liverpool.ac.uk

1 Institute of Integrative Biology, University of Liverpool, Biosciences Building, Crown Street, Liverpool L69 7ZB, UK glycoproteins, including MUC1 [2], MUC2 [3, 4], MUC4 [5], MUC5B and MUC5AC [6, 7]. It also appears to promote cell differentiation and, as such, is involved in the development of lung [7], breast [8], liver [9] and gut [10] tissues.

Expression of AGR2 is induced by physiological stress [11], ER stress [3, 6, 11-14], and is strongly oestrogen- and androgen-responsive, particularly in breast and prostate tissue [15-18]. For this reason, overexpression of AGR2 is often reported in a number of cancers, particularly in those arising from the breast, prostate, ovary and pancreas. In these cancers, higher expression levels of AGR2 generally correlate with decreased patient survival time [5, 19-24]. The reduced survival time is thought to be caused by an increase in the rate of metastasis of AGR2-expressing cancers, as a number of studies have shown an increase in AGR2 expression in metastatic cells relative to their primary tumours [16, 25-31] and importantly, AGR2 was able to induce metastasis of a benign rat mammary cell line when cells overexpressing AGR2 were injected into syngeneic rats [16].

AGR2 is largely tethered to the ER through its C-terminal ER-retention sequence [4, 14, 32-34], but several studies have reported the presence of AGR2 in the extracellular compartment [35-38], although it has never been demonstrated that this AGR2 is not just simply released as a result of cell death and lysis. However, in vivo, AGR2 has been detected in both human colonic mucus [35] and murine intestinal mucus [35-37]. This suggests that AGR2 may have an extracellular role, perhaps in a similar way to nAG, the newt homologue of AGR2, which binds to the cell surface receptor Prod 1 and can induce limb regeneration in a salamander model $[39,40]$. As further evidence of an extracellular role for AGR2, a recent study showed that the addition of extracellular recombinant AGR2 to 
pancreatic cancer cells promoted their growth, migration and invasion by signalling through the $\mathrm{C} 4.4 \mathrm{a}$ cell surface receptor [41]. Interestingly, $\mathrm{C} 4.4 \mathrm{a}$ is a structural homologue of the urokinase-type plasminogen activator receptor (uPAR), which, along with CD59, is the most closely related human homologue of Prod1 [42]. Extracellularlyadded recombinant AGR2 has also been shown to promote adhesion of rat mammary epithelial cells $[16,43]$ and the migration and tube formation of human umbilical vein endothelial cells (HUVEC) [38], indicating a possible role for extracellular AGR2 in the promotion of angiogenesis. Changes in both cell adhesion and induction of angiogenesis may be important for a pro-metastatic phenotype.

The prevalence of AGR2 overexpression in several tumour types and its correlation with patient survival has engendered much interest in the use of AGR2 as a serum or urine biomarker for disease detection [29, 44-47]. Further understanding of the nature of secreted AGR2 may be important in maximising the accuracy and sensitivity of such tests, and may also shed light on the extracellular functions of AGR2. We show here that AGR2 is $O$-glycosylated upon secretion from human and rat cell lines, and that this form of the protein is released from healthy cells and not as a result of cell lysis.

\section{Materials and methods}

\section{Cell culture and transfection}

The oestrogen receptor-positive MCF7A human mammary epithelial cell line was grown in Dulbecco's Modified Eagle's Medium (DMEM, Life Technologies) including non-essential amino acids (NEAA) and supplemented with $10 \%$ (v/v) foetal bovine serum (FBS), $4 \mathrm{mM} \mathrm{L}$-glutamine and $10 \mu \mathrm{g} / \mathrm{mL}$ insulin (Sigma). Rama 37 rat mammary benign epithelial tumour cells [48] were grown in DMEM including NEAA and supplemented with $5 \%$ (v/v) FBS, $4 \mathrm{mM} \mathrm{L}$-glutamine, $10 \mathrm{ng} / \mathrm{mL}$ insulin and $10 \mathrm{ng} / \mathrm{mL}$ hydrocortisone (Sigma). Cells were transfected with the PiggyBac EF1 $\alpha$-IRES-neomycin plasmid vector (Systems Biosciences, vector only), or the same vector containing a human AGR2 cDNA, using FuGENE6 transfection reagent, according to the manufacturer's protocol (Promega). Transfected cells were maintained in normal growth medium supplemented with $1 \mathrm{mg} / \mathrm{mL}$ G418 (Melford). Clonal cell lines were created by serial dilution of transfected cells down to a single cell in a known volume and growing these for several weeks until confluent cultures were obtained.

\section{Collection of conditioned medium}

Cells were grown to $30-40 \%$ confluence, washed four times in phosphate-buffered saline (PBS) supplemented

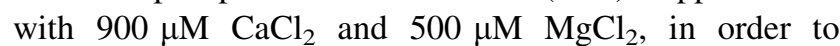
remove the maximum amount of FBS whilst limiting cell detachment. These cells were then incubated in Opti-MEM (Minimum Essential Medium) serum-free medium (Life Technologies) supplemented with a final concentration of $25 \mathrm{mM}$ glucose, $1.8 \mathrm{mM} \mathrm{CaCl}_{2}, 4 \%$ (v/v) non-essential amino acids (NEAA, Life Technologies) and $10 \mathrm{ng} / \mathrm{mL}$ hydrocortisone, in order to make this serum-free medium as close to the formulation of normal culture medium as possible. After $24 \mathrm{~h}$, medium was collected, centrifuged at $1000 \times g$ at $4{ }^{\circ} \mathrm{C}$ and concentrated using an Amicon ultra centrifugal filter (Millipore).

\section{Western blotting}

Whole cell lysates were prepared from cells grown to $70-80 \%$ confluence and lysed in RIPA buffer [50 mM Tris-HCl, pH 6.8, $150 \mathrm{mM} \mathrm{NaCl}, 2 \mathrm{mM}$ EDTA, $1 \%$ (v/v) NP-40, $0.5 \%(\mathrm{w} / \mathrm{v})$ sodium deoxycholate, $0.1 \%(\mathrm{w} / \mathrm{v})$ SDS and complete protease inhibitor cocktail (Roche)]. Secreted protein samples were obtained as described above. Samples were subjected to SDS-PAGE, transferred to PVDF membrane (Millipore) and probed with a mouse monoclonal antibody specific for AGR2 (Millipore, MABC48) or a polyclonal rabbit anti-LDHA (Cell Signaling Technology, \#2012) serum. Horseradish peroxidasecoupled secondary antibodies were obtained from Dako.

Protein molecular weights were estimated by plotting a standard curve of molecular weight and relative migration distance for known protein standards, and calculating the molecular weights of different forms of AGR2 using their relative migration distance.

\section{Enzymatic deglycosylation of proteins}

All enzymes and reagents were acquired from New England Biolabs. Cell lysates and samples of conditioned medium were first denatured by incubation with $0.5 \%(\mathrm{w} / \mathrm{v})$ SDS, $40 \mathrm{mM}$ DTT and subsequent heating at $98{ }^{\circ} \mathrm{C}$ for 5 min. Samples were then subjected to treatment with either PNGase F, $O$-glycosidase/neuraminidase mix or protein deglycosylation mix (consisting of PNGase F, $O$ glycosidase, neuraminidase, $\beta 1-4$ galactosidase and $\beta-N$ acetylglucosaminidase) for $4 \mathrm{~h}$ at $37{ }^{\circ} \mathrm{C}$, as per the manufacturer's instructions. 


\section{Results}

\section{AGR2 is secreted in a higher molecular weight form from cultured rat and human mammary cells}

A number of studies have reported that AGR2 is secreted, both from cultured cells [17, 25, 49] and into intestinal mucus in mice [35]. In the present experiments, AGR2 was recovered from the culture medium of Rama 37 cells expressing wild-type (WT) AGR2 protein and displayed an apparent molecular weight 0.90 ( $\mathrm{SD} \pm 0.12$ ) $\mathrm{kDa}$ higher than that of intracellular AGR2 (Fig. 1). This mass difference in extracellular AGR2 shows that its presence in the culture medium is not due to intracellular AGR2 released from lysed or leaky cells, and this is further confirmed by the lack of detectable levels in the culture medium of AGR2-expressing Rama 37 cells of the intracellular marker protein, lactate dehydrogenase A (LDHA).

To ensure that this release of higher molecular weight AGR2 was not restricted to transfected rat mammary cells, the release of AGR2 from AGR2-expressing human MCF7A cells [16] was investigated (Fig. 2). Furthermore, to investigate further whether this higher molecular weight form is actively released from cells rather than released by cell lysis, MCF7A cells were incubated in increasingly nutrient-poor media, and the presence of AGR2 in these conditioned media was monitored by Western blot (Fig. 2).

All incubation media were serum-free (see "Materials and methods" section), and cells incubated in either DMEM with or without non-essential amino acids
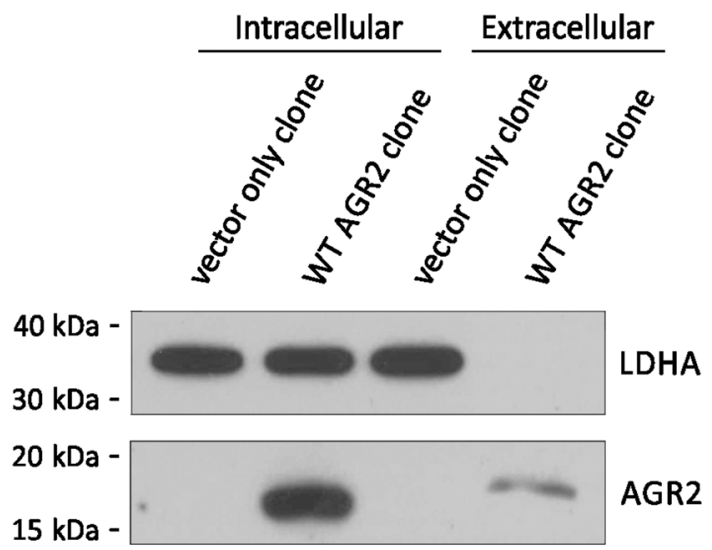

Fig. 1 A higher molecular weight form of AGR2 is released into the medium of AGR2-expressing rat mammary epithelial tumour cells. Conditioned medium was collected from vector only-expressing or WT AGR2-expressing Rama 37 cells and analysed for the presence of AGR2 and lactate dehydrogenase (LDHA) by Western blot. The presence of LDHA in the conditioned medium was used as an indication of the contamination of the secreted protein pool by intracellular proteins [64]. Extracellular AGR2 was $0.90(\mathrm{SD} \pm 0.12)$ $\mathrm{kDa}$ larger than intracellular AGR2 on average $(n=3)$

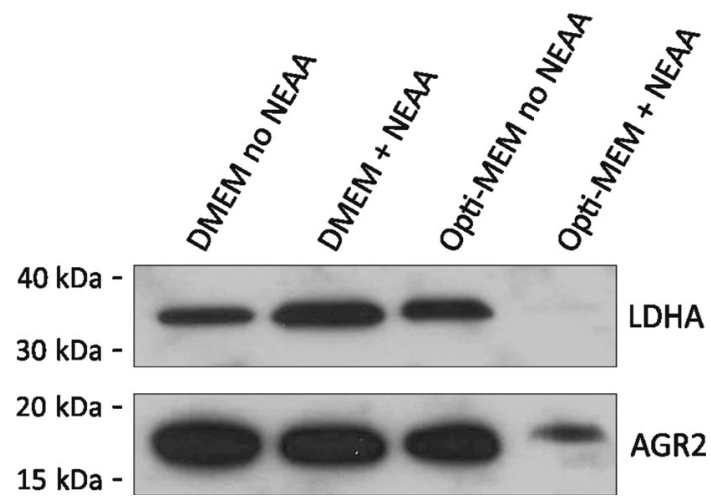

Fig. 2 In human mammary epithelial cells, higher molecular weight AGR2 is only released from non-leaky cells. MCF7A cells were incubated for $24 \mathrm{~h}$ in serum-free DMEM or serum-free Opti-MEM medium, with and without non-essential amino acids (NEAA). Conditioned medium was collected and probed for AGR2 and LDHA by Western blot. The presence of LDHA in the conditioned medium was used as an indication of the contamination of the secreted protein pool by intracellular proteins under each serum-free condition. Extracellular AGR2 was $0.93(\mathrm{SD} \pm 0.09) \mathrm{kDa}$ larger than intracellular AGR2 on average $(n=3)$

(NEAA), or with Opti-MEM medium without NEAA released large amounts of lower molecular weight AGR2 into the culture medium, but there was no detectable higher molecular weight AGR2 under any of these conditions. Furthermore, cells incubated in these media also released high amounts of LDHA, suggesting that AGR2 is released from these cells as a result of cell lysis. Conversely, cells incubated in Opti-MEM medium containing NEAA released a form of AGR2 with apparent molecular weight $0.93(\mathrm{SD} \pm 0.09) \mathrm{kDa}$ larger than intracellular AGR2, but barely detectable levels of LDHA. These data suggest that the higher molecular weight form of AGR2 is released only from intact cells that do not leak intracellular proteins.

\section{Secreted AGR2 contains $O$-linked, but not $N$-linked, glycans}

Given that only small amounts of AGR2 protein are secreted from both Rama 37 and MCF7A cells, we created a Rama 37 cell line expressing a mutant form of AGR2 lacking the C-terminal ER-retention sequence ( $\triangle \mathrm{KTEL}$ AGR2), leading to increased secretion of AGR2, and thus facilitating the determination of the increase in molecular weight of secreted AGR2. As expected, AGR2 was secreted in higher amounts from $\triangle$ KTEL AGR2-expressing cells but, interestingly, secreted $\triangle$ KTEL AGR2 displayed the same sized shift in apparent molecular weight compared to intracellular WT AGR2 (0.94 (SD \pm 0.09$) \mathrm{kDa}$, Fig. 3) as did secreted WT AGR2 (Fig. 1), despite the KTEL deletion rendering the intracellular protein apparently 0.87 


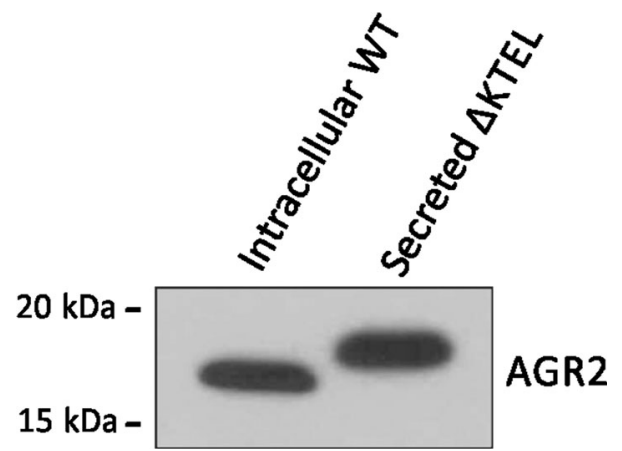

Fig. 3 A highly secreted mutant form of AGR2 is also released in a high molecular weight form from rat mammary tumour cells. Rama 37 cells were engineered to express AGR2 devoid of the C-terminal KTEL ER-retention sequence in order to increase its secretion. Note that, as $\triangle$ KTEL AGR2 is highly secreted, intracellular levels are almost undetectable and thus expression of intracellular WT AGR2 is shown for size comparison. Extracellular AGR2 was 0.94 $(\mathrm{SD} \pm 0.09) \mathrm{kDa}$ larger than intracellular AGR2 on average $(n=3)$

$(\mathrm{SD} \pm 0.01) \mathrm{kDa}$ smaller than intracellular WT AGR2 (measured by polyacrylamide gel electrophoresis, data not shown).

As the majority of secreted proteins are glycosylated [50], it is likely that the cause of the increase in apparent molecular weight of secreted AGR2 was one or more glycosylation events. Indeed, secreted $\triangle$ KTEL AGR2 (but not intracellular WT AGR2) reacted weakly with periodic acid-Schiff stain, a glycoprotein stain (data not shown). Therefore, we investigated the nature of the probable glycosylation using specific deglycosylating enzymes (Fig. 4).

Conditioned medium from $\triangle$ KTEL AGR2-expressing cells treated with the $\mathrm{N}$-glycosidase PNGase F showed no change in the apparent molecular weight of AGR2, remaining $0.80(\mathrm{SD} \pm 0.04) \mathrm{kDa}$ larger than intracellular AGR2, both with and without PNGase $F$ treatment (Fig. 4a). Under these same reaction conditions, however, PNGase $F$ reduced the apparent molecular weight of $\alpha$-acid glycoprotein by approximately $30 \mathrm{kDa}$, indicating that the enzyme was active in the conditioned medium (Fig. 4b). Treatment of $\triangle$ KTEL AGR2-conditioned medium with either $O$-glycosidase (and neuraminidase) or a commercial mix of deglycosylation enzymes, consisting of PNGase F, $O$-glycosidase, neuraminidase, $\beta 1-4$ galactosidase and $\beta-N$ acetylglucosaminidase, reduced the apparent molecular weight of secreted AGR2 by $0.53(\mathrm{SD} \pm 0.04) \mathrm{kDa}$, but not back down to the apparent molecular weight of intracellular AGR2. Deglycosylation enzymes had no effect on the size of intracellular AGR2 (Fig. 4a). These experiments indicate that the secreted form of AGR2 does not contain any detectable $\mathrm{N}$-glycosylation sites, but contains at least one digestible $O$-glycosylation site.

\section{Discussion}

It is shown here for the first time that AGR2 secreted from both rat and human mammary epithelial cells becomes $O$ glycosylated. While it was possible to distinguish that secreted AGR2 was $O$-glycosylated, but not $N$-glycosylated, it is clear that neither treatment with $O$-glycosidase/ neuraminidase nor the deglycosylation enzyme cocktail (Fig. 4) fully reduced the apparent molecular weight of the secreted AGR2 to that of the unmodified intracellular AGR2. This likely reflects the presence of glycan structures not digestible by the enzymes used herein, but while secreted AGR2 is not phosphorylated (data not shown), we cannot totally rule out the presence of some other, less common, post-translational modification. In addition, the similar-sized shift in apparent molecular weight observed between secreted WT and $\triangle$ KTEL AGR2 (Figs. 1, 3), despite the smaller size of the $\triangle$ KTEL polypeptide chain, implies that the secreted $\triangle$ KTEL AGR2 may be more heavily glycosylated than WT protein. The presence of a KTEL sequence has been previously shown to alter the make-up of $O$-linked glycans, and probably relates to the differences in transit time of the protein from ER to Golgi and to the extracellular space [51]. Due to the limitations of the SDS polyacrylamide gel electrophoresis technique, it was not possible to draw further conclusions about the detailed nature of the $O$-linked modifications from size differences of the observed bands.

Possible sites of these $O$-glycosylated residue(s) in AGR2 are shown in Fig. 5, based on prediction by the NetOGlyc 4.0 server [52]. All of these predicted sites lie within the unstructured N-terminal region of AGR2, which we described previously [43], consistent with a recent bioinformatics finding that $O$-glycosylation sites are located preferentially in unstructured protein regions, whereas the opposite is true for $\mathrm{N}$-glycosylation [53].

AGR2 is an ER-resident chaperone protein and other such chaperones have also been reported to be secreted [54-57]. Notably, the AGR2-related protein disulphide isomerase, ERp44, which, like AGR2, contains a divergent CXXS-active site, is $O$-glycosylated upon secretion [57]. It is possible therefore that $O$-glycosylation of normally ERresident chaperones by the Golgi body is a more general phenomenon, rather than an AGR2-specific event, and may stem from 'leakiness' of the KDEL-dependent retrograde transport of proteins from Golgi to ER [51]. Furthermore, although most secreted proteins passing through the Golgi are glycosylated, there are several examples of non-glycosylated secreted proteins, notably insulin [58], serum albumin [59] and elastin [60]. This suggests that glycosylation of secreted ER proteins may have functional consequences, rather than being the result of some default 
a

PNGase F

O-glycosidase

Deglycosylation mix

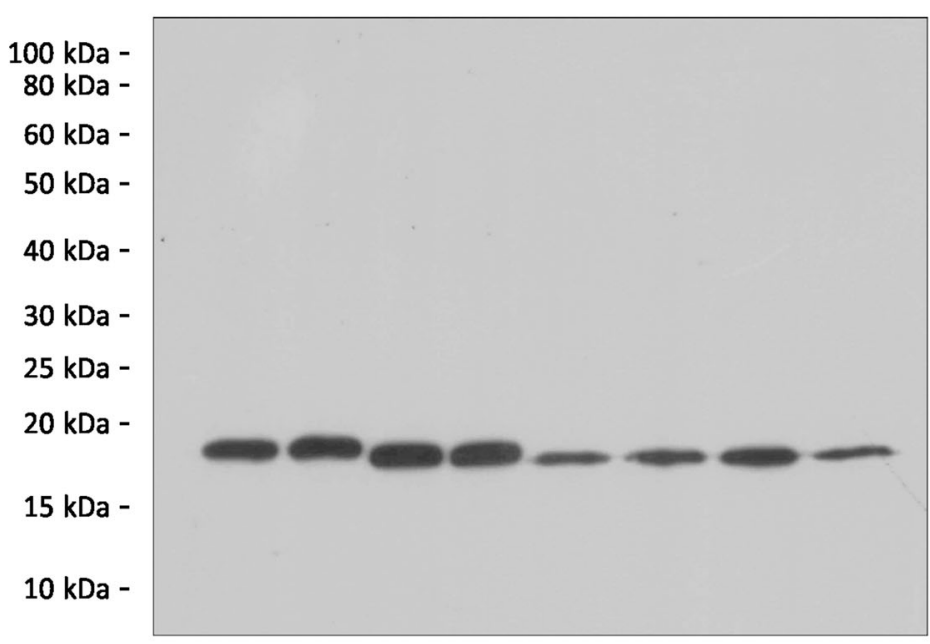

b

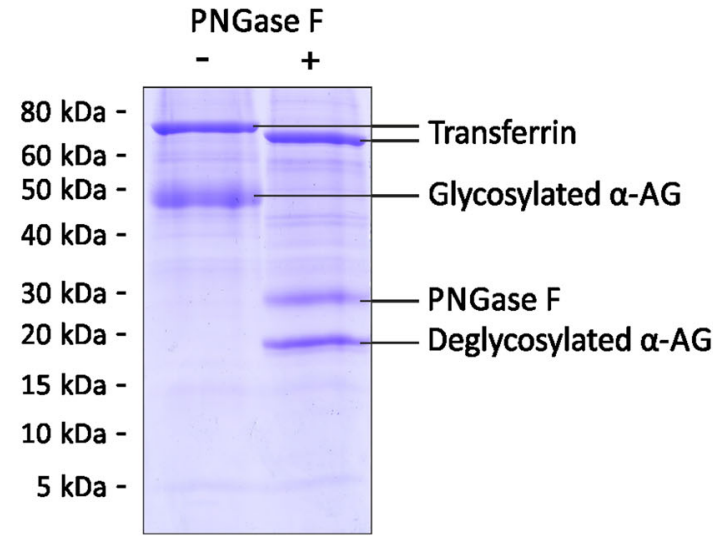

Intracellular

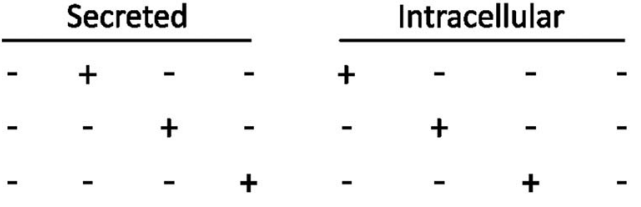

AGR2
Fig. 4 Treatment with $O$-glycosidase reduces the molecular weight of secreted AGR2. a Conditioned medium from $\triangle$ KTEL AGR2expressing cells (secreted AGR2) and whole cell lysate from WT AGR2-expressing cells (intracellular AGR2) were treated with the indicated deglycosylation enzymes for $4 \mathrm{~h}$ at $37{ }^{\circ} \mathrm{C}$, as per the manufacturer's instructions. Treated samples were subjected to Western blot and probed for AGR2. PNGase F is an $N$-glycosidase. $O$-glycosidase-treated samples were simultaneously treated with neuraminidase, as the presence of terminal sialic acid residues blocks the activity of $O$-glycosidase [65]. Deglycosylation mix consists of

programme of glycosylation for any protein passing through the Golgi.

It is not yet known how the presence of the $O$-linked glycosylation might affect the biological activity of AGR2. The protein plays a role in cell adhesion [16, 43], although it should be noted that these experiments were performed using bacterially-derived (i.e. non-glycosylated) AGR2, but it is interesting that $O$-glycosylation status has been reported to influence cell adhesion; for example, in pancreatic
PNGase F, $O$-glycosidase, neuraminidase, $\beta 1-4$ galactosidase and $\beta$ $\mathrm{N}$-acetylglucosaminidase. Untreated extracellular AGR2 was 0.80 $(\mathrm{SD} \pm 0.04) \mathrm{kDa}$ larger than intracellular AGR2 on average $(n=3)$, and extracellular AGR2 treated with $O$-glycosidase or deglycosylation mix was $0.27(\mathrm{SD} \pm 0.04) \mathrm{kDa}$ larger than intracellular AGR2 on average $(n=3)$. b To ensure that PNGase $\mathrm{F}$ was active in the presence of culture medium components, $\alpha$-acid glycoprotein $(\alpha-A G)$ was added to conditioned medium and treated with PNGase as in a. Reaction mixtures were run on an SDS-PAGE gel and stained with Coomassie blue

carcinoma cells, enhancement or reduction of cell adhesion depended upon the cell surface $O$-linked glycosylation state of the cells [61], and similarly, alterations in the $O$-glycosylation patterns of the transmembrane proteins $\alpha_{2} \beta_{1}$ integrin and E-cadherin altered the migratory and invasive potential of pancreatic adenocarcinoma cells [62]. Loss of $O$-glycosylation sites in the secreted metastasis-inducing protein osteopontin was also shown to increase its pro-adhesive effects [63]. Thus, the degree and pattern of $O$ - 
Fig. 5 Predicted $O$ glycosylation sites on secreted AGR2. Amino acids predicted as possible sites of $O$ glycosylation by the NetOGlyc 4.0 server [52] are shaded in grey boxes. Secondary structure elements are shown above the primary sequence. $\alpha: \alpha$-helix. $\beta: \beta$-sheet. Figure adapted from [43]
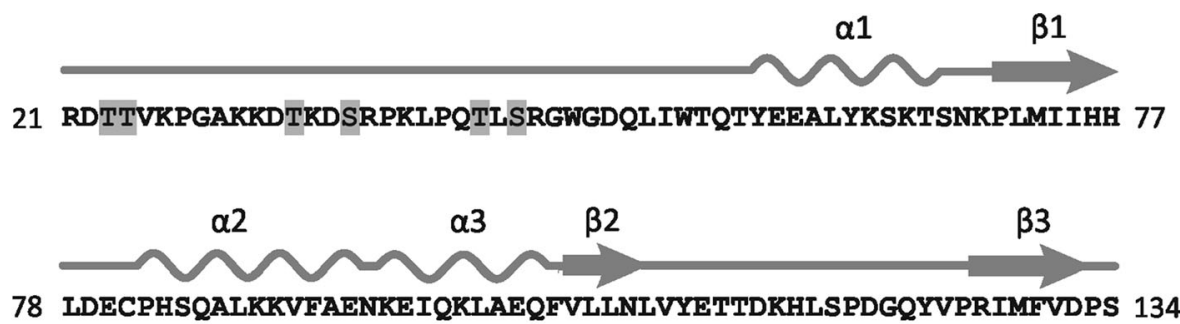

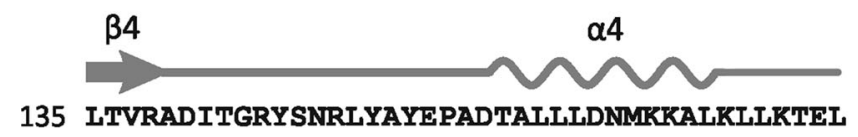

glycosylation in both cell surface and secreted proteins appear to play roles in cell adhesion. We have already shown that the unstructured region of AGR2, comprising amino acids 21-40, is required for AGR2-promoted cell adhesion [43], and we have shown here that it is also the possible site of $O$-linked glycosylation in AGR2 (Fig. 5). Glycosylation of extracellular AGR2 may therefore be important for AGR2-mediated cell adhesion.

\begin{abstract}
Acknowledgments The authors thank Dr. Mark Wilkinson for kindly providing the $\alpha$-acid glycoprotein, and Dr. Edwin Yates for critically reviewing the manuscript. The authors thank the Medical Research Council for a 4-year research studentship and a Centenary Award to CC, and the Cancer and Polio Research Fund Ltd. for core research support.
\end{abstract}

\section{Compliance with Ethical Standards}

Conflict of interest The authors have no conflict of interest.

Open Access This article is distributed under the terms of the Creative Commons Attribution 4.0 International License (http://crea tivecommons.org/licenses/by/4.0/), which permits unrestricted use, distribution, and reproduction in any medium, provided you give appropriate credit to the original author(s) and the source, provide a link to the Creative Commons license, and indicate if changes were made.

\section{References}

1. Persson S, Rosenquist M, Knoblach B, Khosravi-Far R, Sommarin M, Michalak M (2005) Diversity of the protein disulfide isomerase family: identification of breast tumor induced Hag2 and Hag3 as novel members of the protein family. Mol Phylogenet Evol 36(3):734-740. doi:10.1016/j.ympev.2005.04.002

2. Norris AM, Gore A, Balboni A, Young A, Longnecker DS, Korc M (2013) AGR2 is a SMAD4-suppressible gene that modulates MUC1 levels and promotes the initiation and progression of pancreatic intraepithelial neoplasia. Oncogene 32(33):3867-3876. doi:10.1038/onc.2012.394

3. Zhao F, Edwards R, Dizon D, Afrasiabi K, Mastroianni JR, Geyfman M, Ouellette AJ, Andersen B, Lipkin SM (2010) Disruption of Paneth and goblet cell homeostasis and increased endoplasmic reticulum stress in Agr2-/- mice. Dev Biol 338(2):270-279. doi:10.1016/j.ydbio.2009.12.008
4. Park SW, Zhen G, Verhaeghe C, Nakagami Y, Nguyenvu LT, Barczak AJ, Killeen N, Erle DJ (2009) The protein disulfide isomerase AGR2 is essential for production of intestinal mucus. Proc Natl Acad Sci USA 106(17):6950-6955. doi:10.1073/pnas. 0808722106

5. Brychtova V, Hermanova M, Karasek P, Lenz J, Selingerova I, Vojtesek B, Kala Z, Hrstka R (2014) Anterior gradient 2 and mucin 4 expression mirrors tumor cell differentiation in pancreatic adenocarcinomas, but aberrant anterior gradient 2 expression predicts worse patient outcome in poorly differentiated tumors. Pancreas 43(1):75-81. doi:10.1097/MPA.0b013e3182a63bc3

6. Schroeder BW, Verhaeghe C, Park SW, Nguyenvu LT, Huang X, Zhen G, Erle DJ (2012) AGR2 is induced in asthma and promotes allergen-induced mucin overproduction. Am J Respir Cell Mol Biol 47(2):178-185. doi:10.1165/rcmb.2011-04210C

7. Zhou M, Chen HL, Cheng S, Mei L, Zhang HL, Xie M, Xiong WN, Xu YJ (2013) Effect of dexamethasone on expression of AGR2 protein in asthmatic mice. J Huazhong Univ Sci Technol Med Sci 33(1):33-36. doi:10.1007/s11596-013-1067-1

8. Verma S, Salmans ML, Geyfman M, Wang H, Yu Z, Lu Z, Zhao F, Lipkin SM, Andersen B (2012) The estrogen-responsive Agr2 gene regulates mammary epithelial proliferation and facilitates lobuloalveolar development. Dev Biol 369(2):249-260. doi:10. 1016/j.ydbio.2012.06.030

9. Lepreux S, Bioulac-Sage P, Chevet E (2011) Differential expression of the anterior gradient protein-2 is a conserved feature during morphogenesis and carcinogenesis of the biliary tree. Liver Int 31(3):322-328. doi:10.1111/j.1478-3231.2010.02438.X

10. Gupta A, Wodziak D, Tun M, Bouley DM, Lowe AW (2013) Loss of anterior gradient 2 (Agr2) expression results in hyperplasia and defective lineage maturation in the murine stomach. J Biol Chem 288(6):4321-4333. doi:10.1074/jbc.M112.433086

11. Zweitzig DR, Smirnov DA, Connelly MC, Terstappen LW, O'Hara SM, Moran E (2007) Physiological stress induces the metastasis marker AGR2 in breast cancer cells. Mol Cell Biochem 306(1-2):255-260. doi:10.1007/s11010-007-9562-y

12. Di Maro G, Salerno P, Unger K, Orlandella FM, Monaco M, Chiappetta G, Thomas G, Oczko-Wojciechowska M, Masullo M, Jarzab B, Santoro M, Salvatore G (2014) Anterior gradient protein 2 promotes survival, migration and invasion of papillary thyroid carcinoma cells. Mol Cancer 13:160. doi:10.1186/14764598-13-160

13. Ryu J, Park SG, Lee PY, Cho S, Lee do H, Kim GH, Kim JH, Park BC (2013) Dimerization of pro-oncogenic protein Anterior Gradient 2 is required for the interaction with BiP/GRP78. Biochem Biophys Res Commun 430(2):610-615. doi:10.1016/j.bbrc. 2012.11.105

14. Higa A, Mulot A, Delom F, Bouchecareilh M, Nguyen DT, Boismenu D, Wise MJ, Chevet E (2011) Role of pro-oncogenic 
protein disulfide isomerase (PDI) family member anterior gradient 2 (AGR2) in the control of endoplasmic reticulum homeostasis. J Biol Chem 286(52):44855-44868. doi:10.1074/jbc. M111.275529

15. Wilson CL, Sims AH, Howell A, Miller CJ, Clarke RB (2006) Effects of oestrogen on gene expression in epithelium and stroma of normal human breast tissue. Endocr Relat Cancer 13(2):617-628. doi:10.1677/erc.1.01165

16. Liu D, Rudland PS, Sibson DR, Platt-Higgins A, Barraclough R (2005) Human homologue of cement gland protein, a novel metastasis inducer associated with breast carcinomas. Cancer Res 65(9):3796-3805. doi:10.1158/0008-5472.CAN-04-3823

17. Zhang JS, Gong A, Cheville JC, Smith DI, Young CY (2005) AGR2, an androgen-inducible secretory protein overexpressed in prostate cancer. Genes Chromosomes Cancer 43(3):249-259. doi:10.1002/gcc.20188

18. Bu H, Schweiger MR, Manke T, Wunderlich A, Timmermann B, Kerick M, Pasqualini L, Shehu E, Fuchsberger C, Cato AC, Klocker H (2013) Anterior gradient 2 and 3-two prototype androgen-responsive genes transcriptionally upregulated by androgens and by oestrogens in prostate cancer cells. FEBS J 280(5):1249-1266. doi:10.1111/febs.12118

19. Innes HE, Liu D, Barraclough R, Davies MP, O’Neill PA, PlattHiggins A, de Silva Rudland S, Sibson DR, Rudland PS (2006) Significance of the metastasis-inducing protein AGR2 for outcome in hormonally treated breast cancer patients. Br J Cancer 94(7):1057-1065. doi:10.1038/sj.bjc.6603065

20. Barraclough DL, Platt-Higgins A, de Silva Rudland S, Barraclough R, Winstanley J, West CR, Rudland PS (2009) The metastasis-associated anterior gradient 2 protein is correlated with poor survival of breast cancer patients. Am J Pathol 175(5):1848-1857. doi:10.2353/ajpath.2009.090246

21. Barraclough DL, Sewart S, Rudland PS, Shoker BS, Sibson DR, Barraclough R, Davies MP (2010) Microarray analysis of suppression subtracted hybridisation libraries identifies genes associated with breast cancer progression. Cell Oncol 32(1-2):87-99. doi:10.3233/CLO-2009-0499

22. Zhang Y, Forootan SS, Liu D, Barraclough R, Foster CS, Rudland PS, Ke Y (2007) Increased expression of anterior gradient-2 is significantly associated with poor survival of prostate cancer patients. Prostate Cancer Prostatic Dis 10(3):293-300. doi:10. 1038/sj.pcan.4500960

23. Darb-Esfahani S, Fritzsche F, Kristiansen G, Weichert W, Sehouli J, Braicu I, Dietel M, Denkert C (2012) Anterior gradient protein 2 (AGR2) is an independent prognostic factor in ovarian high-grade serous carcinoma. Virchows Arch 461(2):109-116. doi:10.1007/s00428-012-1273-4

24. Riener MO, Pilarsky C, Gerhardt J, Grutzmann R, Fritzsche FR, Bahra M, Weichert W, Kristiansen G (2009) Prognostic significance of AGR2 in pancreatic ductal adenocarcinoma. Histol Histopathol 24(9):1121-1128

25. Park K, Chung YJ, So H, Kim K, Park J, Oh M, Jo M, Choi K, Lee EJ, Choi YL, Song SY, Bae DS, Kim BG, Lee JH (2011) AGR2, a mucinous ovarian cancer marker, promotes cell proliferation and migration. Exp Mol Med 43(2):91-100

26. Inoue M, Hiyama K, Nakabayashi K, Morii E, Minami M, Sawabata N, Shintani Y, Nakagiri T, Susaki Y, Maeda J, Higashiyama M, Okami J, Yoshida Y, Ding J, Otomo Y, Okumura M (2012) An accurate and rapid detection of lymph node metastasis in non-small cell lung cancer patients based on one-step nucleic acid amplification assay. Lung Cancer 78(3):212-218. doi:10. 1016/j.lungcan.2012.08.018

27. Yu H, Zhao J, Lin L, Zhang Y, Zhong F, Liu Y, Yu Y, Shen H, Han M, He F, Yang P (2012) Proteomic study explores AGR2 as pro-metastatic protein in HCC. Mol BioSyst 8(10):2710-2718. doi:10.1039/c2mb25160d
28. Zhang Y, Ali TZ, Zhou H, D’Souza DR, Lu Y, Jaffe J, Liu Z, Passaniti A, Hamburger AW (2010) ErbB3 binding protein 1 represses metastasis-promoting gene anterior gradient protein 2 in prostate cancer. Cancer Res 70(1):240-248. doi:10.1158/00085472.CAN-09-2904

29. Smirnov DA, Zweitzig DR, Foulk BW, Miller MC, Doyle GV, Pienta KJ, Meropol NJ, Weiner LM, Cohen SJ, Moreno JG, Connelly MC, Terstappen LW, O'Hara SM (2005) Global gene expression profiling of circulating tumor cells. Cancer Res 65(12):4993-4997. doi:10.1158/0008-5472.CAN-04-4330

30. Sweeny L, Liu Z, Bush BD, Hartman Y, Zhou T, Rosenthal EL (2012) CD147 and AGR2 expression promote cellular proliferation and metastasis of head and neck squamous cell carcinoma. Exp Cell Res 318(14):1788-1798. doi:10.1016/j.yexcr.2012.04.022

31. Li Y, Lu J, Peng Z, Tan G, Liu N, Huang D, Zhang Z, Duan C, Tang X, Tang F (2014) $N, N^{\prime}$-dinitrosopiperazine-mediated AGR2 is involved in metastasis of nasopharyngeal carcinoma. PLoS One 9(4):e92081. doi:10.1371/journal.pone.0092081

32. Dumartin L, Whiteman HJ, Weeks ME, Hariharan D, Dmitrovic B, Iacobuzio-Donahue CA, Brentnall TA, Bronner MP, Feakins RM, Timms JF, Brennan C, Lemoine NR, Crnogorac-Jurcevic T (2011) AGR2 is a novel surface antigen that promotes the dissemination of pancreatic cancer cells through regulation of cathepsins B and D. Cancer Res 71(22):7091-7102. doi:10.1158/ 0008-5472.CAN-11-1367

33. Gray TA, Alsamman K, Murray E, Sims AH, Hupp TR (2014) Engineering a synthetic cell panel to identify signalling components reprogrammed by the cell growth regulator anterior gradient-2. Mol BioSyst 10(6):1409-1425. doi:10.1039/c4mb00113c

34. Gupta A, Dong A, Lowe AW (2012) AGR2 gene function requires a unique endoplasmic reticulum localization motif. J Biol Chem 287(7):4773-4782. doi:10.1074/jbc.M111.301531

35. Bergstrom JH, Berg KA, Rodriguez-Pineiro AM, Stecher B, Johansson ME, Hansson GC (2014) AGR2, an endoplasmic reticulum protein, is secreted into the gastrointestinal mucus. PLoS One 9(8):e104186. doi:10.1371/journal.pone.0104186

36. Johansson ME, Phillipson M, Petersson J, Velcich A, Holm L, Hansson GC (2008) The inner of the two Muc2 mucin-dependent mucus layers in colon is devoid of bacteria. Proc Natl Acad Sci USA 105(39):15064-15069. doi:10.1073/pnas.0803124105

37. Johansson ME, Thomsson KA, Hansson GC (2009) Proteomic analyses of the two mucus layers of the colon barrier reveal that their main component, the Muc2 mucin, is strongly bound to the Fcgbp protein. J Proteome Res 8(7):3549-3557. doi:10.1021/ pr9002504

38. Hong XY, Wang J, Li Z (2013) AGR2 expression is regulated by HIF-1 and contributes to growth and angiogenesis of glioblastoma. Cell Biochem Biophys 67(3):1487-1495. doi:10.1007/ s12013-013-9650-4

39. Kumar A, Godwin JW, Gates PB, Garza-Garcia AA, Brockes JP (2007) Molecular basis for the nerve dependence of limb regeneration in an adult vertebrate. Science 318(5851):772-777. doi: $10.1126 /$ science. 1147710

40. da Silva SM, Gates PB, Brockes JP (2002) The newt ortholog of CD59 is implicated in proximodistal identity during amphibian limb regeneration. Dev Cell 3(4):547-555

41. Arumugam $\mathrm{T}$, Deng $\mathrm{D}$, Bover $\mathrm{L}$, Wang $\mathrm{H}$, Logsdon $\mathrm{CD}$, Ramachandran V (2015) New blocking antibodies against novel AGR2-C4.4A pathway reduce growth and metastasis of pancreatic tumors and increase survival in mice. Mol Cancer Ther 14(4):941-951. doi:10.1158/1535-7163.MCT-14-0470

42. Garza-Garcia A, Harris R, Esposito D, Gates PB, Driscoll PC (2009) Solution structure and phylogenetics of Prod1, a member of the three-finger protein superfamily implicated in salamander limb regeneration. PLoS One 4(9):e7123. doi:10.1371/journal. pone. 0007123 
43. Patel P, Clarke C, Barraclough DL, Jowitt TA, Rudland PS, Barraclough R, Lian LY (2013) Metastasis-promoting anterior gradient 2 protein has a dimeric thioredoxin fold structure and a role in cell adhesion. J Mol Biol 425(5):929-943. doi:10.1016/j. jmb.2012.12.009

44. Edgell TA, Barraclough DL, Rajic A, Dhulia J, Lewis KJ, Armes JE, Barraclough R, Rudland PS, Rice GE, Autelitano DJ (2010) Increased plasma concentrations of anterior gradient 2 protein are positively associated with ovarian cancer. Clin Sci (Lond) 118(12):717-725. doi:10.1042/CS20090537

45. Wayner EA, Quek SI, Ahmad R, Ho ME, Loprieno MA, Zhou Y, Ellis WJ, True LD, Liu AY (2012) Development of an ELISA to detect the secreted prostate cancer biomarker AGR2 in voided urine. Prostate 72(9):1023-1034. doi:10.1002/pros.21508

46. Chen R, Pan S, Duan X, Nelson BH, Sahota RA, de Rham S, Kozarek RA, McIntosh M, Brentnall TA (2010) Elevated level of anterior gradient-2 in pancreatic juice from patients with premalignant pancreatic neoplasia. Mol Cancer 9:149. doi:10.1186/ 1476-4598-9-149

47. Shi T, Gao Y, Quek SI, Fillmore TL, Nicora CD, Su D, Zhao R, Kagan J, Srivastava S, Rodland KD, Liu T, Smith RD, Chan DW, Camp DG 2nd, Liu AY, Qian WJ (2014) A highly sensitive targeted mass spectrometric assay for quantification of AGR2 protein in human urine and serum. $J$ Proteome Res 13(2):875-882. doi:10.1021/pr400912c

48. Dunnington DJ, Hughes CM, Monaghan P, Rudland PS (1983) Phenotypic instability of rat mammary tumor epithelial cells. J Natl Cancer Inst 71(6):1227-1240

49. Ramachandran V, Arumugam T, Wang H, Logsdon CD (2008) Anterior gradient 2 is expressed and secreted during the development of pancreatic cancer and promotes cancer cell survival. Cancer Res 68(19):7811-7818. doi:10.1158/0008-5472.CAN-081320

50. Bosques CJ, Raguram S, Sasisekharan R (2006) The sweet side of biomarker discovery. Nat Biotechnol 24(9):1100-1101. doi:10. 1038/nbt0906-1100

51. Martire G, Mottola G, Pascale MC, Malagolini N, Turrini I, Serafini-Cessi F, Jackson MR, Bonatti S (1996) Different fate of a single reporter protein containing KDEL or KKXX targeting signals stably expressed in mammalian cells. J Biol Chem 271(7):3541-3547

52. Steentoft C, Vakhrushev SY, Joshi HJ, Kong Y, Vester-Christensen MB, Schjoldager KT, Lavrsen K, Dabelsteen S, Pedersen NB, Marcos-Silva L, Gupta R, Bennett EP, Mandel U, Brunak S, Wandall HH, Levery SB, Clausen H (2013) Precision mapping of the human O-GalNAc glycoproteome through SimpleCell technology. EMBO J 32(10):1478-1488. doi:10.1038/emboj.2013.79

53. Sargeant DP, Gryk MR, Maciejewski MW, Thapar V, Kundeti V, Rajasekaran S, Romero P, Dunker K, Li SC, Kaneko T, Schiller MR (2012) Secondary structure, a missing component of sequence-based minimotif definitions. PLoS One 7(12):e49957. doi:10.1371/journal.pone.0049957

54. Rauschert N, Brandlein S, Holzinger E, Hensel F, Muller-Hermelink HK, Vollmers HP (2008) A new tumor-specific variant of GRP78 as target for antibody-based therapy. Lab Invest 88(4):375-386. doi:10.1038/labinvest.2008.2

55. Zhang Y, Liu R, Ni M, Gill P, Lee AS (2010) Cell surface relocalization of the endoplasmic reticulum chaperone and unfolded protein response regulator GRP78/BiP. J Biol Chem 285(20):15065-15075. doi:10.1074/jbc.M109.087445

56. Jakobsen CG, Rasmussen N, Laenkholm AV, Ditzel HJ (2007) Phage display derived human monoclonal antibodies isolated by binding to the surface of live primary breast cancer cells recognize GRP78. Cancer Res 67(19):9507-9517. doi:10.1158/00085472.CAN-06-4686

57. Sannino S, Anelli T, Cortini M, Masui S, Degano M, Fagioli C, Inaba K, Sitia R (2014) Progressive quality control of secretory proteins in the early secretory compartment by ERp44. J Cell Sci 127(19):4260-4269. doi:10.1242/jcs. 153239

58. Heinemann L, Hompesch M (2014) Biosimilar insulins: basic considerations. J Diabetes Sci Technol 8(1):6-13. doi:10.1177/ 1932296813516958

59. Quinlan GJ, Martin GS, Evans TW (2005) Albumin: biochemical properties and therapeutic potential. Hepatology 41(6):1211-1219. doi:10.1002/hep. 20720

60. Patel A, Fine B, Sandig M, Mequanint K (2006) Elastin biosynthesis: the missing link in tissue-engineered blood vessels. Cardiovasc Res 71(1):40-49. doi:10.1016/j.cardiores.2006.02. 021

61. Sawada T, Ho JJ, Sagabe T, Yoon WH, Chung YS, Sowa M, Kim YS (1993) Biphasic effect of cell surface sialic acids on pancreatic cancer cell adhesiveness. Biochem Biophys Res Commun 195(2):1096-1103. doi:10.1006/bbrc.1993.2157

62. Bassaganas S, Carvalho S, Dias AM, Perez-Garay M, Ortiz MR, Figueras J, Reis CA, Pinho SS, Peracaula R (2015) Pancreatic cancer cell glycosylation regulates cell adhesion and invasion through the modulation of alpha2beta1 integrin and E-cadherin function. PLoS One 9(5):e98595. doi:10.1371/journal.pone. 0098595

63. Kariya Y, Kanno M, Matsumoto-Morita K, Konno M, Yamaguchi Y, Hashimoto Y (2014) Osteopontin O-glycosylation contributes to its phosphorylation and cell-adhesion properties. Biochem J 463(1):93-102. doi:10.1042/BJ20140060

64. Goergen JL, Marc A, Engasser JM (1993) Determination of cell lysis and death kinetics in continuous hybridoma cultures from the measurement of lactate dehydrogenase release. Cytotechnology 11(3):189-195

65. Koutsioulis D, Landry D, Guthrie EP (2008) Novel endo-alpha$\mathrm{N}$-acetylgalactosaminidases with broader substrate specificity. Glycobiology 18(10):799-805. doi:10.1093/glycob/cwn069 